\title{
Zoning of water requirement satisfaction index for common bean in Mato Grosso
}

\author{
William Fenner ${ }^{1}$, Rivanildo Dallacort ${ }^{1}$, Flávio C. Dalchiavon ${ }^{2}$, \\ Adalberto Santi' ${ }^{3}$, Fabrício S. da Silva ${ }^{4} \&$ João D. Barbieri ${ }^{1}$ \\ ${ }^{1}$ Universidade do Estado de Mato Grosso/Programa de Pós-Graduação em Ambiente e Sistemas de Produção Agrícola. Tangará da Serra, MT. \\ E-mail: fennerwilliam@gmail.com (Corresponding author); rivanildo@unemat.br; jd.barbieri@hotmail.com \\ ${ }^{2}$ Instituto Federal de Educação, Ciência e Tecnologia de Mato Grosso/Departamento de Agronomia. Campo Novo do Parecis, MT. E-mail: \\ flavio.dalchiavon@cnp.ifmt.edu.br \\ ${ }^{3}$ Universidade do Estado de Mato Grosso/Departamento de Agronomia. Tangará da Serra, MT. E-mail: adalbertosanti@unemat.br \\ ${ }^{4}$ Universidade do Estado de Mato Grosso/Programa de Pós-Graduação em Ambiente e Sistemas de Produção Agrícola. Barra do Bugres, MT. \\ E-mail: fabricio@unemat.br
}

\section{Key words:}

Phaseolus vulgaris

geotechnology

geostatistics

sowing dates

\begin{abstract}
A B S T R A C T
The aim of this study was the agroclimatic zoning of common bean in the Mato Grosso state in the second harvest. Data from 38 meteorological stations in the state and in neighboring regions were used. The zoning was based on water requirement satisfaction index (WRSI) for the common bean crop, for the three levels of available water capacity of the soils of the state $(30,50$ and $75 \mathrm{~mm})$ in 12 sowing periods. After generating the indexes for the municipalities, the variograms of the data were fitted in order to enable interpolation of the data for the state. Data were entered into ArcGIS ${ }^{\mathrm{TM}} 10.0$ and the ordinary kriging interpolation method was used. After generating the maps, they were clipped to the Mato Grosso State and classified as the following WRSI classes: suitable (WRSI $\geq 0.65$ ); restricted $(0.55<$ WRSI $<0.65)$ and unsuitable (WRSI $\leq 0.55)$ for the stage of flowering and grain filling. It was possible to interpolate only the ten-day periods 8 to 12, because from 1 to 7 all regions of the state are suitable for cultivation. The trend of the aptitude of sowing dates is similar to the movement of the air masses active in the state, with a northwest-southeast direction of displacement.
\end{abstract}

\section{Palavras-chave:}

Phaseolus vulgaris geotecnologias geoestatística épocas de semeadura

\section{Zoneamento do índice de satisfação de necessidade hídrica do feijoeiro comum no Mato Grosso}

\section{R E S U M O}

O objetivo deste trabalho foi realizar o zoneamento do Índice de Satisfação de Necessidade de Água (ISNA) da cultura do feijoeiro para o Estado de Mato Grosso em segunda safra. Utilizaram-se dados de temperatura e precipitação provenientes de 38 estações meteorológicas distribuídas no Estado e em regiões vizinhas. O zoneamento foi realizado com base no ISNA para a cultura do feijoeiro, para três classes de Capacidade de Água Disponível (CAD) dos solos do Estado (30, 50 e $75 \mathrm{~mm}$ ), para 12 épocas de semeadura. Gerados os índices para as estações procedeu-se ao ajuste de variogramas para possibilitar a interpolação dos dados para o Estado. Os dados foram inseridos no ArcGIS ${ }^{\mathrm{TM}} 10.0$ e o método interpolador krigagem ordinária foi o utilizado. Gerados os mapas foram recortadas e classificadas, para o Estado de Mato Grosso, as seguintes classes: Apta (ISNA $\geq 0,65$ ); Restrita $(0,55<$ ISNA $<0,65)$ e Inapta $(\leq 0,55)$ para a fase de florescimento e enchimento de grãos. Foi possível a interpolação apenas do decêndio 8 ao 12, pois do 1 ao 7 todas as regiões do Estado são aptas ao cultivo. O comportamento da aptidão das épocas de semeadura é semelhante ao deslocamento das massas de ar atuantes no Estado, com sentido de deslocamento noroeste-sudeste. 


\section{INTRODUCTION}

Located in the Midwest region of Brazil, Mato Grosso has an area of $903,357.91 \mathrm{~km}^{2}$ distributed into 141 municipalities (SEPLAN, 2011). The state stands out as the main agricultural producer in the country, producing soybean, maize, cotton, rice and bean (CONAB, 2014).

The predominant cultivation system for all crops is rainfed, which is highly susceptible to the meteorological instabilities, such as droughts, dry spells and severe winters. Common bean (Phaseolus vulgaris L.), object of this study, due to its cultivation period (second harvest), as well as maize and rice, has its risk maximized because of the cultivation close to the end of the rainy period (Andrade et al., 2006). In this context, geostatistics and simulation models are used to predict variables and create scenarios, allowing to generate zonings, thus indicating the best sowing periods with lower risks to the crop.

In this context, spatialization and interpolation of meteorological data, which have the zoning as the product, are fundamental in a state with the dimensions of Mato Grosso. Farias et al. (2001) characterized the occurrence of water deficit for the soybean crop in producing regions of Brazil, based on the water balance and on the Water Requirement Satisfaction Index (WRSI) with the aid of geostatistics.

Recently, Viola et al. (2010) and Marcuzzo (2014) obtained satisfactory results using geostatistics and kriging in studies on rainfall distribution in the states of Minas Gerais and Mato Grosso do Sul.

The objective of this study was to perform the zoning of the sowing periods of second-harvest common bean in Mato Grosso, based on the WRSI and on the available water capacity.

\section{Material AND Methods}

The study consisted in the following steps: $\mathrm{i}$ - analysis of meteorological data and WRSI calculation for the stations; ii - fit of the semivariograms and data interpolation; and iii - classification of the maps and sum of unsuitable, restricted and suitable areas for each period.

The zoning used ten-day data of rainfall and temperature (maximum, mean and minimum) of 38 weather stations located in the Mato Grosso state and surroundings with at least 12 years of observation (2000 to 2012). These data were obtained through the website Agritempo, belonging to the EMBRAPA (Brazilian Agricultural Research Corporation), which contains data from stations of the INMET (National Institute of Meteorology) and CPTEC (State and Environmental Secretariat - RO). The software program CLIMA (Faria et al., 2003) was used to tabulate the data, verify the consistency, organize the means and fill possible gaps.

The maps were generated by spatializing the mean values of WRSI that varied from zero to one and indicate the ratio between the actual crop evapotranspiration (ETr) and the potential crop evapotranspiration (ETp), representing the relationship between the amount of water available and the demand to guarantee maximum yield using the following aptitude classes: suitable (WRSI $\geq 0.65)$; b) restricted $(0.55<$ WRSI $<0.65)$ and c) unsuitable (WRSI $\leq 0.55)$ (Farias et al., 2001).
The WRSI values were calculated through the relationship between the actual crop evapotranspiration and the potential evapotranspiration of reference, in an EXCEL ${ }^{\mathrm{TM}}$ worksheet (Rolim et al., 1998), which were compared with the critical stage of the crop (15 days before flowering until grain filling) (Andrade et al., 2006).

The WRSI values were calculated for 12 sowing periods (Table 1) for the three levels of Available Water Capacity (AWC) of the soil (30,50 and $75 \mathrm{~mm}$ ) according to the classification proposed by Sans et al. (2001). The map of soils of the Mato Grosso State was used to classify the soils in their respective AWCs.

After data verification and tabulation, semivariograms were fitted, selecting the model that best fitted, according to the parameters ' $\mathrm{C}_{0}$ ' (nugget effect), ' $\mathrm{C}_{0}+\mathrm{Cl}^{\prime}$ ' (sill), 'a' (range) and degree of spatial dependence (DSD), obtained by the ratio between the nugget effect and the sill $\left(\mathrm{C} 1 / \mathrm{C}_{0}+\mathrm{C} 1\right)$, which were classified according to Dalchiavon \& Carvalho (2012), with the following interpretation for DSD: DSD $<20 \%=$ very low spatial dependence of the variable (VL); $20 \%<$ DSD $<$ $40 \%=$ low dependence $(\mathrm{L}) ; 40 \%<\mathrm{DSD}<60 \%=$ intermediate dependence $(\mathrm{I}) ; 60 \%<\mathrm{DSD}<80 \%=$ high dependence $(\mathrm{H})$ and $80 \%<\mathrm{DSD}<100 \%$ = very high dependence $(\mathrm{VH})$.

Then, WRSI data were imported to the Software ArcGIS ${ }^{\mathrm{TM}}$ version 10.0 , followed by interpolation through the kriging method. Lastly, zoning maps of the aptitude classes of common bean sowing periods for the Mato Grosso state were generated.

Table 1. Common bean sowing periods considered for the zoning based on WRSI

\begin{tabular}{cc}
\hline Period (ten days) & Date \\
1 & January 01 to 10 \\
2 & January 11 to 20 \\
3 & January 21 to 31 \\
4 & February 01 to 10 \\
5 & February 11 to 20 \\
6 & February 21 to 28 \\
7 & March 01 to 10 \\
8 & March 11 to 20 \\
9 & March 21 to 31 \\
10 & April 01 to 10 \\
11 & April 11 to 20 \\
12 & April 21 to 30 \\
\hline
\end{tabular}

\section{Results AND Discussion}

The spatial distribution of WRSI for Mato Grosso is very similar for the three AWCs (Figures 1, 2 and 3). Such similarity can be attributed to the water regime, displacements of air masses acting on the state and also to the biomes that comprise it: Amazon, Cerrado and Pantanal (Marcuzzo et al., 2011). The dry season in the region occurs from May to September, period with the lowest values of cumulative rainfall, and from October on, the rainy period starts (Marcuzzo et al., 2011).

For the sowing periods 01 to 07 , there was no spatial variability in the WRSI values. Thus, the periods 01 to 07 (January 1 to March 10) can be considered as suitable (WRSI > 0.65) for all the Mato Grosso state at AWC of 30 $\mathrm{mm}$. Figure 1 shows the zoning maps of the common bean based on the WRSI for the sowing periods 08 to 12 (March 20 to April 10). 

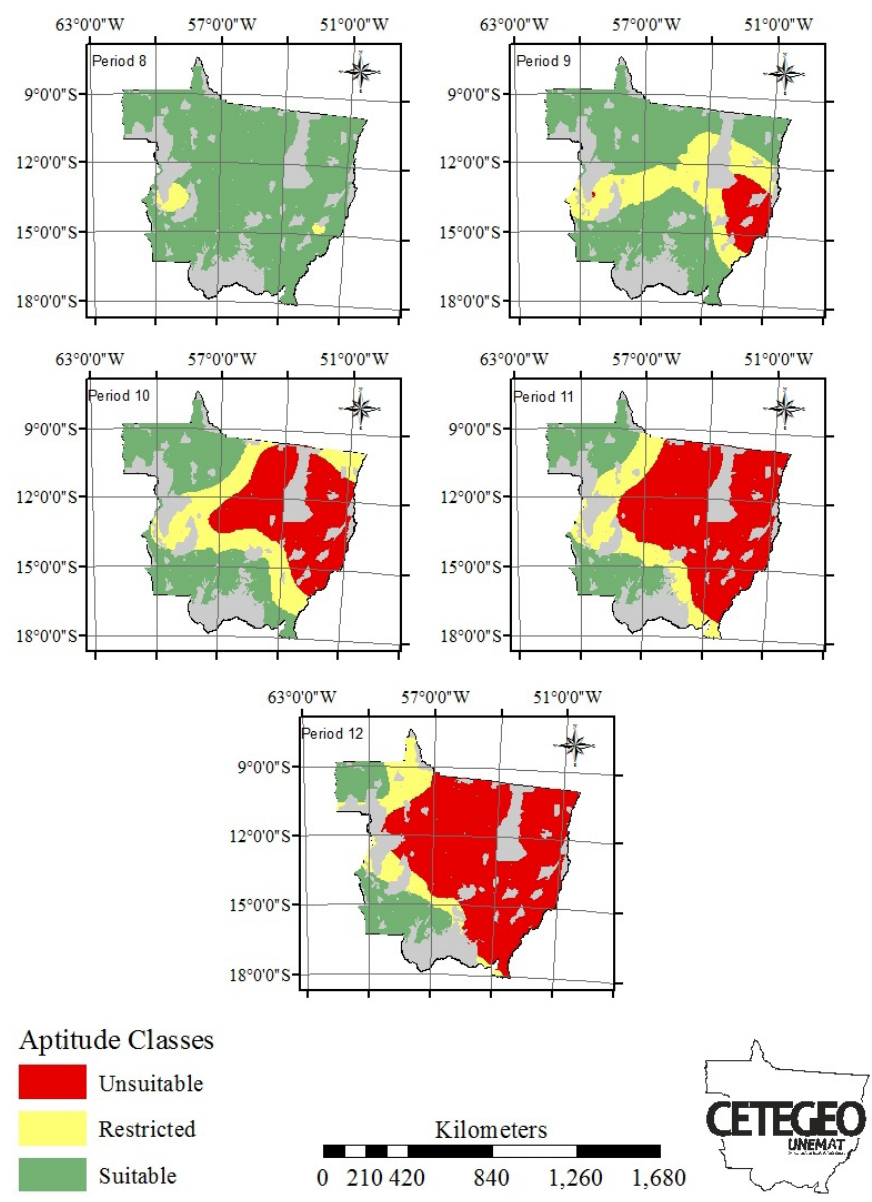

Figure 1. Zoning of common bean sowing risk classes for the Mato Grosso state based on the Water Requirement Satisfaction Index and on AWC of $30 \mathrm{~mm}$

The regions concentrated to the Northeast of the state are the last ones to enter in the classes restricted and unsuitable for common bean sowing (Figure 1), and the opposite was observed to the Southeast, where the regions are the first ones to enter the classes restricted and unsuitable for the common bean crop.

From the sowing period 10 on (April 1), restricted regions for cultivation considerably increased in the state, mainly due to the end of the rainy season, characteristic in these periods.

Marcuzzo et al. (2011), in a study on rainfall distribution and seasonality in Mato Grosso, with data from 75 pluviometric stations of the National Water Agency (ANA) and 30 years of observation, found that the rainfalls in the state move from the Northwest to the Southeast, possibly due to the action of the atmospheric mechanisms acting on the state. In the spring and summer, the equatorial air masses specifically and directly influence the behavior of the rainfalls.

This characteristic behavior is due to the advance and retreat of the rainfalls in the state, since they start in the North and Northeast regions and, as the rainy season advances, move into the state until reaching the East and South regions (Figure 1).

It is noticed that, when the rainy period approaches the end, the rainfalls decrease considerably in the East and South regions and retreat as they started, but in the opposite way, i.e., the North and Northeast regions will be the last ones to stop the rains and will show the highest cumulative values.
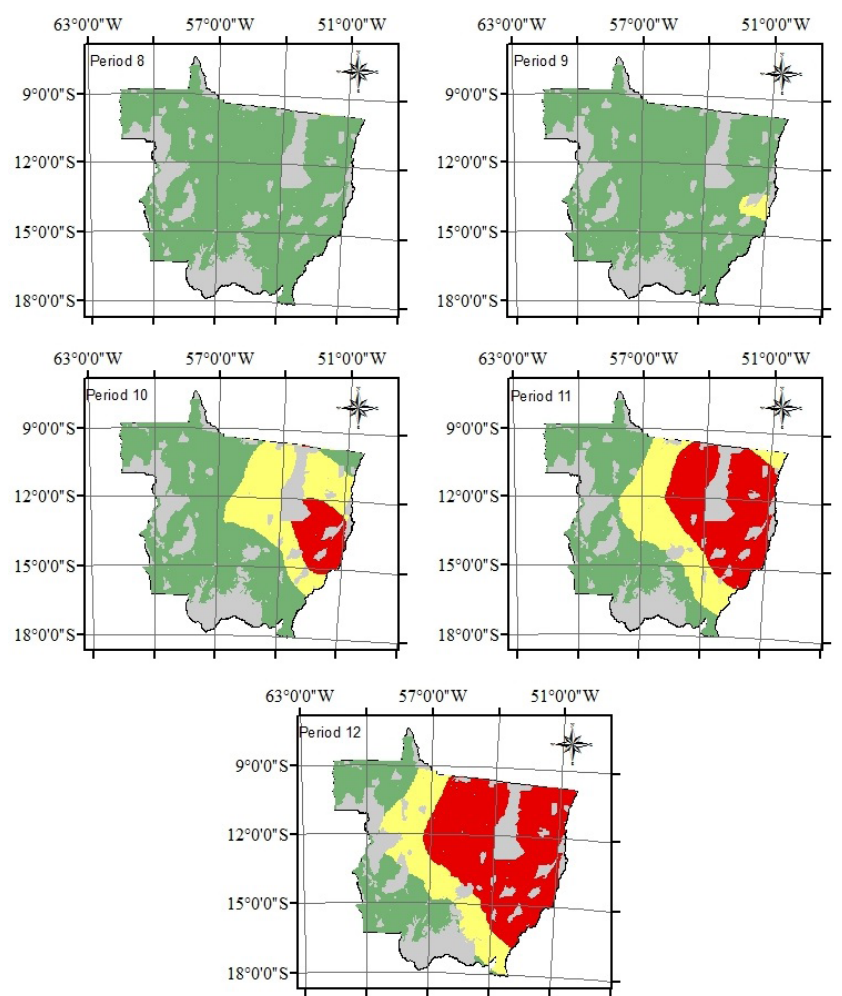

Aptitude Classes

Unsuitable

Restricted

Suitable

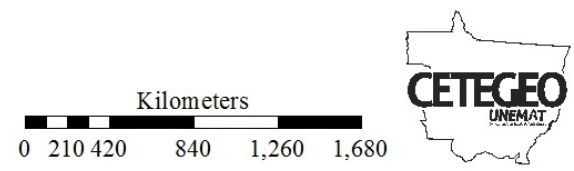

Figure 2. Zoning of common bean sowing risk classes for the Mato Grosso state based on the Water Requirement Satisfaction Index and on AWC of $50 \mathrm{~mm}$

Another plausible explanation for this behavior is the vegetation of the state, because it is composed of three large biomes (Amazon, Cerrado and Pantanal). In the Amazon, with the highest humidity levels, there is a predisposition to higher cumulative rainfalls, followed by the Cerrado and Pantanal, whose rainfall levels are lower (Marcuzzo \& Costa, 2012). The study on rainfall distribution is important because it directly influences the development of the common bean crop for the different sowing periods in the state.

Figure 2 shows the zoning maps of common bean for the Mato Grosso state for the sowing periods from 8 to 12 and AWC of $50 \mathrm{~mm}$.

As observed for AWC of $30 \mathrm{~mm}$ (Figure 1), but with lower intensity for the AWC of $50 \mathrm{~mm}$, Figure 2 shows the distribution of risk classes of common bean sowing in the Mato Grosso state. In unsuitable regions (WRSI $<0.55$ ), there are the sowing periods $09,10,11$ and 12 (March 20 to April 30), and the period 09 showed low intensity, only in the Mid-East of the state. Such behavior is due to a larger amount of water available in the soil, which reflects in the water balance and, consequently, in the WRSI values.

In the initial sowing periods, when the rainy season is still full, there is higher water availability, increasing the values of WRSI, while the increment of water availability favors plant development with lower risk.

Evaluating the different sowing periods for the common bean crop as a function of different spacings in Selvíria, Mato 

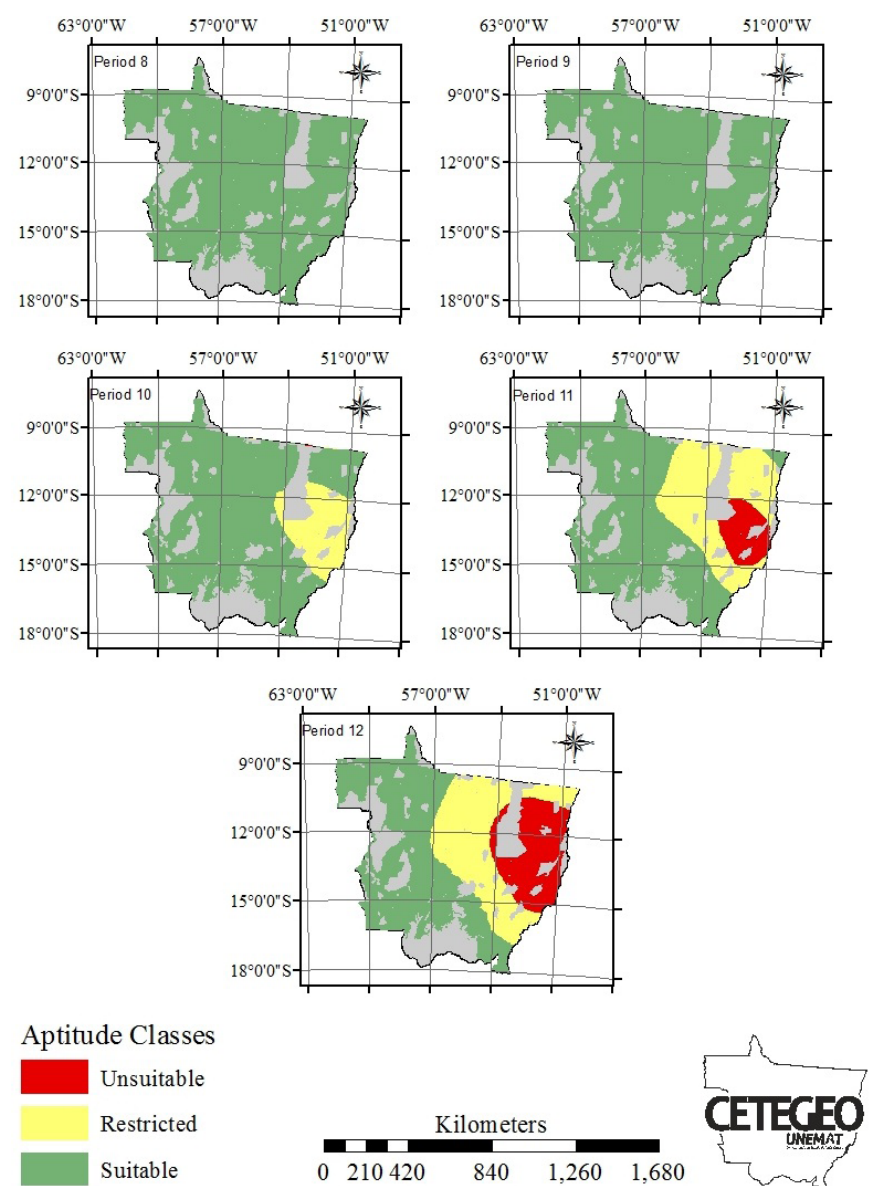

Figure 3. Zoning of common bean sowing risk classes for the Mato Grosso state based on the Water Requirement Satisfaction Index and on AWC of $75 \mathrm{~mm}$

Grosso do Sul, Carvalho et al. (1998) observed the significant influence of the sowing period on its yield. As an explanation, the authors attributed this result to the extreme sensitivity of the common bean crop to the climate variability.

Figure 3 shows the zoning of the common bean crop and sowing risk classes based on WRSI spatialization for the Mato Grosso state for AWC of $75 \mathrm{~mm}$.

For this AWC, there are more suitable areas (WRSI > 0.65) for common bean cultivation in the Mato Grosso state. Unsuitable areas occur only from the Northeast to the Southeast of the state, with higher expression in the sowing periods 11 and 12 (April 20 to 30), with predominance of suitable areas in most of the state.

In a study on the mapping of rainfall for the Southern region of Minas Gerais, Ávila et al. (2009) observed influence of the local vegetation and of the transition between dry and rainy periods on the rainfall variability for the region. In addition, the authors also claim that information generated by the zoning can assist farmers in the decision-making regarding sowing periods, soil management and dimensioning of irrigation systems.

The generated maps were used to sum the areas $\left(\mathrm{km}^{2}\right)$ corresponding to unsuitable, restricted and suitable areas, excluding those protected by law, Indian reservations, permanent preservation areas and urban areas, totaling $694,854.67 \mathrm{~km}^{2}$ of available areas. Table 2 shows the total of unsuitable, restricted and suitable areas for the respective sowing periods.
Table 2. Unsuitable, restricted and suitable areas $\left(\mathrm{km}^{2}\right)$ for the Mato Grosso state considering AWCs of 30, 50 and $75 \mathrm{~mm}$

\begin{tabular}{ccccc}
\hline \multirow{2}{*}{$\begin{array}{c}\text { Period/ } \\
\text { AWC }\end{array}$} & \multicolumn{5}{c}{ Area $\left(\mathbf{k m}^{2}\right)$} \\
\cline { 2 - 5 } & Unsuitable & \multicolumn{4}{c}{ Restricted } & Suitable & Total \\
8 & 0 & 4817.21 & 149134.83 & 153952.04 \\
9 & 20372.22 & 31802.60 & 101777.22 & 153952.04 \\
10 & 46224.90 & 43852.22 & 63891.92 & 153969.05 \\
11 & 83117.65 & 37170.48 & 33663.90 & 153952.04 \\
12 & 104804.10 & 21794.26 & 27352.80 & 153952.04 \\
\hline \multicolumn{5}{c}{$50 \mathrm{~mm}$} \\
8 & 0 & 0 & 849.82 & 849.82 \\
9 & 0 & 0 & 849.82 & 849.82 \\
10 & 0 & 0 & 849.82 & 849.82 \\
11 & 0 & 0 & 849.82 & 849.82 \\
12 & 0 & 0 & 849.82 & 849.82 \\
\hline \multicolumn{5}{c}{$75 \mathrm{~mm}$} \\
8 & 0 & 0 & 540052.82 & 540052.82 \\
9 & 0 & 0 & 540052.82 & 540052.82 \\
10 & 0 & 69470.15 & 470582.67 & 540052.82 \\
11 & 37089.05 & 169027.92 & 333935.85 & 540052.82 \\
12 & 91728.20 & 180022.80 & 268301.85 & 540052.82 \\
\hline \multicolumn{5}{c}{}
\end{tabular}

It is evident the difference of climatic risk due to the soil classes and sowing periods, confirming the importance of studies on zoning for different sowing periods. The climatic risk is higher for soils with low water storage capacity $(30 \mathrm{~mm})$ and, for soils with high water storage capacity (AWC of $75 \mathrm{~mm}$ ), plant development is guaranteed by the water supply promoted by the soil, even in periods of transition between the rainy and dry seasons.

It should be emphasized that classifying an area as unsuitable for cultivation does not mean that this area is not useful or cannot be cultivated, because, with the adoption of adequate techniques such as irrigation and drainage, it is possible to cultivate it, making it productive, with risks during the common bean cultivation that can be reduced.

\section{Conclusions}

1. For the ten-day sowing periods 1 to 7 (January 1 to March 10), regardless of the available water capacity (AWC), the entire Mato Grosso state is suitable for the second-harvest common bean cultivation.

2. All the state is suitable for cultivation in the periods 8 (March 20) (AWC $30 \mathrm{~mm}$ ), 8 and 9 (March 20 to 30) (AWC 50 and $75 \mathrm{~mm}$ ). The state has restricted areas from the sowing period 9 (March 31) (AWC $30 \mathrm{~mm}$ ), 10 (April 10) (AWC 50 and $75 \mathrm{~mm}$ ). Unsuitable regions for cultivation are observed from the period 9 (March 31) (AWC $30 \mathrm{~mm}$ ), 10 (April 10) (AWC $50 \mathrm{~mm}$ ) and (April 20) (AWC $75 \mathrm{~mm}$ ).

3. The properties of the soil and its structural management contribute to defining the zoning of the aptitude classes for common bean sowing.

\section{ACKNOWLedgments}

To the National Council for Scientific and Technological Development ( $\mathrm{CNPq})$, for the financial support through the Research Project 'Aplicação e transferência de tecnologias na otimização de sistemas agrícolas sustentáveis' (CNPq Process 
564112/2010-0, call MCT/CNPq/FNDCT/FAPs/MEC/CAPES/ PRO-CENTRO-OESTE No 031/2010).

To the Coordination for the Improvement of Higher Education Personnel (CAPES), for granting the scholarship.

\section{Literature Cited}

Andrade, M. J. B.; Carvalho, A. J.; Vieira, N. M. B. Feijão. 1.ed. Viçosa: UFV, 2006. 600p.

Ávila, L. F.; Mello, C. R. de; Viola, M. R. Mapeamento da precipitação mínima provável para o sul de Minas Gerais. Revista Brasileira de Engenharia Agrícola e Ambiental, v.13, p.906-915, 2009. https:// doi.org/10.1590/S1415-43662009000700013

Carvalho, M. A. C. de; Arf, O.; Sá, M. E. de. Efeito do espaçamento e época de semeadura sobre o desempenho do feijão. I. Produção de semente. Revista Brasileira de Sementes, v.20, p.195-201, 1998. https://doi.org/10.17801/0101-3122/rbs.v20n1p195-201

CONAB - Companhia Nacional de Abastecimento. Feijão: Série histórica de produção <http://www.conab.gov.br/ conteudos.php?a=1252\&t=\&Pagina_objcmsconteudos=2\#A_ objcmsconteudos>. Acessado em 12 Dez. 2014.

Dalchiavon, F. C.; Carvalho, M. de P. e. Correlação linear e espacial dos componentes de produção e produtividade da soja. Semina: Ciências Agrárias, v.33, p.541-552, 2012. https://doi. org/10.5433/1679-0359.2012v33n2p541

Faria, R. T. de; Caramori, P. H.; Chibana, E. Y.; Brito, L. R. de S.; Nakamura, A. K.; Ferreira, A. R. CLIMA - Programa computacional para organização e análise de dados meteorológicos. Revista Engenharia Agrícola, v.23, p.372-387, 2003.
Farias, J. R. B.; Assad, E. D.; Almeida, I. R. de; Evangelista, B. A.; Lazzarotto, C.; Neumaier, N.; Nepomuceno, A. L. Caracterização de risco de déficit hídrico nas regiões produtoras de soja no Brasil. Revista Brasileira de Agrometeorologia, v.9, p.415-421, 2001.

Marcuzzo, F. F. N. Distribuição espacial da sazonalidade da precipitação pluviométrica no Mato Grosso do Sul e estudo de anomalias interanual. Acta Geográfica, v.8, p.22-39, 2014.

Marcuzzo, F. F. N.; Costa, H. de C. Estudo da sazonalidade das chuvas no Estado de Mato Grosso do Sul e sua distribuição espaçotemporal. Revista Brasileira de Geografia Física, v.5, p.73-86, 2012.

Marcuzzo, F. F. N.; Melo, D. C. de R.; Rocha, M. H. Distribuição espaço-temporal e sazonalidade das chuvas no Estado do Mato Grosso. Revista Brasileira de Recursos Hídricos, v.16, p.157-167, 2011. https://doi.org/10.21168/rbrh.v16n4.p157-167

Rolim, G. S.; Sentelhas, P. C.; Barbieri, V. Planilhas no ambiente EXCEL ${ }^{\mathrm{TM}}$ para os cálculos de balanços hídricos: Normal, sequencial, de cultura e de produtividade real e potencial. Revista Brasileira de Agrometeorologia, v.6, p.133-137, 1998.

Sans, L. M. A.; Assad, E. D.; Guimarães, D. P.; Avellar, G. Zoneamento de riscos climáticos para a cultura do milho na Região Centro Oeste do Brasil e para o Estado de Minas Gerais. Revista Brasileira de Agrometeorologia, v.9, p.527-535, 2001.

SEPLAN - Secretaria de Estado e Planejamento. Mato Grosso em números. 1.ed. Cuiabá: Central de Texto, 2011. 144p.

Viola, M. R.; Mello, C. R. de; Pinto, D. B. F.; Mello, J. M. de; Ávila, L. F. Métodos de interpolação espacial para o mapeamento da precipitação pluvial. Revista Brasileira de Engenharia Agrícola e Ambiental, v.14, p.970-978, 2010. https://doi.org/10.1590/S141543662010000900009 